\title{
Empowering Teenage English Language Learners Through Creative Projects
}

\section{Mari Nakamura \\ English Square Kanazawa}

\section{Reference Data:}

Nakamura, M. (2020). Empowering teenage English language learners through creative projects. In P. Clements, A. Krause, \& R. Gentry (Eds.), Teacher efficacy, learner agency. Tokyo: JALT. https://doi.org/10.37546/JALTPCP2019-09

Research shows that Japanese students' motivation for English study tends to decline as they move through their schooling and that secondary-level students' schoolwork-related anxiety rises as they grow older. In this practice-oriented paper, I first discuss the learning background and needs of junior and senior high school students at my private language school. I then describe small-scale "creative projects" that I design and implement with the aim of fostering the students' intrinsic motivation for English language learning and to improve their confidence in expressing and discussing original ideas in English. The description of a sample project illustrates the project goal, class profile, and project procedure. My reflective comments regarding the effectiveness of the project in achieving the above-mentioned goals are also provided. Finally, the limitations of creative projects and possibilities of further improvements are discussed.

数々のリサーチが日本の中高生の英語学習への意欲は学年が上がるほどに減退し、彼らの学習についての不安は成長と ともに高まると示唆している。の実践報告レポートでは、ず筆者の主宰する民間英語教室での中高生の学習状呮と彼らが 有する独特のーーズを自己決定理論と内発的動機べけに関する理論の観点を通して紹介する。次に、彼らの英語学習への内 発的動機を育み、英語で独自のアイディアを表現する自信を高めるために当校で閏登、実施している小規模な創造的プロジェ

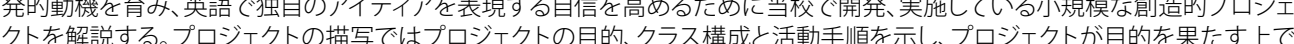

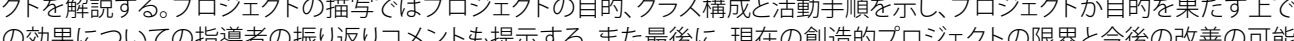
性を述べる。

esearch suggests that Japanese students' motivation for English study tends to decline as they move through their schooling (Benesse Educational Research and Development Institute, 2014; Carreira, 2006; Matsuno, 2018; Sakai, 2009; Yamamori,
2004). In addition, a longitudinal study by the Ministry of Education, Culture, Sports, Science and Technology of Japan (MEXT, 2019) reported that secondary school students' anxiety over grades rises from the 1st year of junior high school to the 2nd year of high school, and the Organisation for Economic Co-operation and Development (OECD, 2017) indicated that 15-year-old students in Japan have higher schoolwork-related anxiety than those of the other countries surveyed in the report. These research findings match with my secondary-level students' perceptions of studying English at public school and anxiety about the frequently administered exams at their schools and cram schools. How my students express such attitudes and views in my classrooms is discussed in the following section.

In an effort to tackle these issues as the teacher and curriculum designer at my own private English language school, I have been implementing small-scale "creative projects." These projects are aimed at promoting my secondary school students' intrinsic motivation for and confidence in learning English through a focus on high-interest topics, production of original work, and active interaction with peers in a low-anxiety learning environment. In this paper, I examine my secondary school students' needs, introduce one of the creative projects aimed at meeting their needs, and explore the effectiveness of the project as a way to achieve the above-mentioned goals.

\section{Background}

As the sole teacher and curriculum designer at my language school, I started to teach secondary school students in small groups in 2008. Observing the students who participate in these classes as a voluntary after-school activity, I have come to realize that many of the students exhibit low motivation for English language learning at their public schools. During talks at the beginning of each lesson and discussions related to school and learning, they repeatedly express the following perceptions of English classes at their public schools: 
- Due to too much testing and pressure to excel at entrance exams, the students feel they are incompetent. Even the students who are earning good grades tend to express anxiety about term tests and entrance exams (low sense of competence and high anxiety).

- Most of the lessons are teacher-centered, and the students do not have much interaction with their peers in class. Some say that the classes at my school are the only place where they engage in meaningful interaction in English that goes beyond language pattern practice (perceived lack of relatedness with classmates)

- Much of home study time is spent on rote memorization of vocabulary and grammatical rules, and students are offered few opportunities to think critically, make decisions by themselves, or reflect upon their own learning (insufficient opportunities to exercise autonomy).

What can be inferred from these revelations by the students is that their learning experience at public schools does not satisfy and may even defy the three basic psychological needs-competence, relatedness, and autonomy-advocated by Ryan and Deci (2000) as an integral part of self-determination theory. Competence refers to human beings' need to feel effectiveness and mastery; relatedness concerns the feeling of social connection; autonomy is the need to self-regulate one's experiences and actions. According to Ryan and Deci (2008), lack of satisfaction of these needs predicts motivational depletion.

In detailing self-determination theory, Deci and Ryan (1985) also stated that human motivation can be influenced by intrinsic (self-determined) and extrinsic (controlled) motivation. Intrinsic motivation refers to behaviors that are concerned with experiencing one's own satisfaction, happiness, and curiosity; extrinsic motivation is concerned with behaviors for the purpose of receiving extrinsic reward such as grades and praise. In discussing the importance of self-determination for human well-being in general, Deci and Ryan held that the ability to make choices and manage interaction with the environment needs to be met to maintain a person's intrinsic motivation. They concluded that "social contextual factors that afford people the opportunity to satisfy their needs for autonomy, competence, and relatedness will facilitate intrinsic motivation" (Deci \& Ryan, 1994, p. 7)

In second language learning the importance of extrinsic motivation, as well as that of intrinsic motivation, has been debated and acknowledged with a focus on integrative motivation, or the desire to integrate oneself into the target language community, and instrumental motivation, or the desire to have pragmatic gains (Brown, 2000; Dörnyei
\& Ushioda, 2013; Gardner, 1983; Gardner, 1985). In the EFL context, learners are often situated in an environment in which their desire to integrate themselves into the English language community tends to be low due to the lack of either opportunities to interact with users of the target language or the perceived necessity to do so. Therefore, the importance of intrinsic motivation is paramount in promoting their desire to learn (Oxford \& Shearin, 1994).

Having gained insights into my students' perceptions of their learning environment at public school through conversations with them over the years and knowing the importance of intrinsic motivation for EFL learners, I have worked on curriculum innovation. After much trial and error, in 2013 I started to implement creative projects through which my students develop intrinsic motivation for learning and confidence by engaging in the investigation of and discussion about high-interest topics with peers in a relaxed atmosphere.

\section{Student Profile and Overview of Creative Projects}

Student Profile

As of the 2019 academic year, 33 secondary-level students are learning English at my private language school in Kanazawa City, Japan. All of these students go to local public schools where English classes meet four times a week for 50 minutes. At my school, classes for 1st- and 2nd-year junior high school students meet three to four times a month; classes for 3rd-year junior high school students and senior high school students meet twice a month. Each class consists of six to seven students with approximately the same proficiency level, and the instruction time per lesson is 75 minutes.

\section{Overview of Creative Projects}

As a vehicle to achieve the aforementioned goals, I implement creative projects that are designed based on the pedagogical approach of project-based learning (PBL) in these classes. PBL is defined as "an active student-centred form of instruction which is characterised by students' autonomy, constructive investigations, goal-setting, collaboration, communication and reflection within real-world practices" (Kokotsaki, Menzies, \& Wiggins, 2016, p. 1). This approach has been widely discussed as an effective instructional model in English language classrooms in recent studies, and a number of guides and frameworks of instructional models have been published (e.g., Beckett \& Slater, 2005; Buck Institute for Education, 2018; Farouck, 2016; Harmer, 2015; Tsiplakides \& Fragoulis, 2009). 
One of the key features of PBL is a constructive investigation that is a "goal-directed process that involves inquiry, knowledge building, and resolution" (Thomas, 2000 , p. 3). In project work, students engage in an investigation with a clear goal in mind, often referred to as a driving question, for a relatively long period of time. During such a constructive investigation, they gradually learn to drive their own learning through trial and error and develop cognitive competence, with scaffolding by the teacher. They also interact with their peers actively not only to share their own ideas and findings but also to learn different perspectives and co-construct new knowledge, thus nurturing a sense of relatedness among the learners. This investigative process of PBL encourages students to engage in autonomous learning (Smithers, 2014), which is one of the keys to promoting intrinsic motivation as self-determination theory informs.

I decided to design creative projects while referring to the principles of PBL with the belief that this key aspect, constructive investigation, would help promote students'(a) motivation and confidence in actually putting the linguistic knowledge they have acquired at public schools to use, (b) their autonomous learning skills, and (c) their sense of relatedness with their classmates, consequently achieving the educational goal at my school. However, care was taken not to be constrained by any specific frameworks or guides in the literature in order to accommodate the unique learning environment at the school, namely the limited instruction time (two to four 75-minute lessons per month), which is much shorter than that of public secondary schools.

The characteristics of the creative projects discussed in this paper are as follows:

- A theme that is relevant to secondary-level students' lives is chosen for each project.

- The expected outcome is clearly communicated to the students before they embark on an investigation.

- Carefully planned support that enables students to complete their tasks in a limited time is provided.

- Scaffolding to encourage critical thinking is provided during the discussion and reflection stages.

- Each student's voice and choice are respected throughout the process.

- Students produce their work in visual and literal forms independently as homework assignments.

- Students discuss their work and the rationale behind their decisions with their peers through oral communication.

- An opportunity for self-reflection is offered at the end of the project.

- Each project is completed in two to four lessons.

\section{A Sample Creative Project at the School: Description and Teacher}

\section{Reflection}

This section introduces a creative project designed by referring to both self-

determination theory and PBL and conducted with a group of high school students at my school. The project goal, student profiles, the project procedure, and my reflective comments on the effectiveness of the project in achieving the goals mentioned in previous sections of this paper are presented. The reflective comments are based on my ongoing classroom observations and notes as well as feedback from the students. Permission to use the data collected in class was obtained through a written agreement with the students and their parents in advance.

\section{Project: Create a New Osechi Dish}

In this project, students created a poster that illustrated an original osechi dish, a traditional Japanese meal that is served on New Year's Day, with both illustrations and text. It was conducted in a class of seven 1st-year high school students. The pedagogical goal of this project was to promote students' intrinsic motivation for learning and confidence in language use while fostering relatedness among them through timed discussions about their original work in a low-anxiety atmosphere.

Project Procedure:

1. I prepared several photographs of osechi dishes and made matching sentence strips that described the dishes (e.g., baked shrimp - The curved body and antennae symbolize longevity.)

2. In class, I introduced the topic of osechi dishes and asked the students what their favorite dishes were and why. I also asked if they knew any historical or cultural meanings associated with the dishes.

3. The students formed pairs and received a set of osechi dish photographs and sentence strips. They matched the photographs to the written descriptions.

4. The students worked as a whole class and checked if they had the same ideas. Then they discussed which ones they thought were interesting. During the discussion, I clarified the meanings of any words or phrases that the students were having difficulty understanding.

5. I facilitated a whole-class discussion on how people in the past decided on the menu of osechi dishes and helped students become aware of two characteristics in their 
origins. Some dishes were chosen to be part of the feast because of their shape; for example, kurikinton (a sweet potato and chestnut paste) looks like a block of gold, which symbolizes fortune. Other dishes were selected because of a play on words; for example, daidai, a tangerine, sounds like "from generation to generation" in Japanese.

6. Each student thought up an original osechi dish and made a poster at home. The poster was to explain what the dish was made of and the reasons why the dish was thought to bring good luck in the new year.

7. The students brought their posters to the following class and explained them in small groups of two to three students. They repeated this with different partners three times to build fluency and confidence in interacting in English. As the discussions progressed, they were assigned a shorter time: 5 minutes for the first turn, 4 minutes for the second turn, and 3 minutes for the third turn. This timeddiscussion task was based on the $4 / 3 / 2$ fluency-building technique developed by Maurice (1983), with the aim of giving the students positive pressure to express their thoughts without hesitation. During the discussions, they made positive comments about their classmates' work, focusing on the originality of the ideas, and asked questions for clarification if necessary.

8. After finishing the project, the students responded to a post-project questionnaire survey. The purpose was twofold: to offer students an opportunity to reflect on their own learning, which is an integral part of learner autonomy (Brown, 2004), and to give me insights into the students' perceptions of the project.

\section{Teacher Reflection}

Each student brought some unique ideas to the creation of an original osechi dish and actively engaged in the discussion with classmates. The students used a variety of communication strategies such as rephrasing, repetition, and code-switching to carry on the conversations during the timed-discussion activity, which indicates their high motivation to have meaningful interactions among themselves.

Here is an example of a student's use of the rephrasing technique during the second round of timed discussion. Student A is explaining her original dish to her partner.

Student A: The meaning of this is longevity.

Student B: Uh.
Student A: (barely audible) Long life.

Student B: I see.

The following interactional sample, during the final timed discussion, shows how a student switched codes and rephrased what he had uttered to get his meaning across.

Student C: The round shape means that life goes on.

Student D: (silence)

Student C: guruguru [going around] ... [gesture of moving a finger around] means life ...etto [well]... continues a long time.

Student D: Oh! That's funny.

In the post-project questionnaire survey, students were required to write their reflections on

1. the investigative and creative stages of their project;

2. their impression of their friends' posters;

3. the timed-discussion activity.

A space for them to write other comments was also provided. Given their limited command of the English language, the students were advised to make their comments in their L1, Japanese.

The survey results showed that this project had positive impacts on the students' intrinsic motivation. The most notable and positive comments were given to the question regarding impressions of classmates' work (Question 2). All students mentioned that they were surprised to see their classmates' ideas, that they learned things they had not thought of, and that they enjoyed learning new information and perspectives from their friends. One noted, "My classmates' personalities shone through in the ideas and the ways they presented, and it was so stimulating!" Comments like this suggest that the students felt enjoyment in co-constructing knowledge with their peers, which contributed to the promotion of relatedness among themselves.

Regarding the investigative and creative stages of their projects (Question 1), four students mentioned that the discussion of the patterns commonly seen in the traditional dishes conducted during the first lesson helped them come up with their own ideas. This indicates that the facilitation given before the individual investigation, which is an 
integral part of PBL (Berkeley, 2017; Ertmer \& Simons, 2006), was effective in preparing the students to take risks and make their own decisions in creating their original dishes. Two students wrote that they had never worked on this sort of creative project at their public schools and that they found it inspiring.

Regarding the timed-discussion activity (Question 3), two students wrote that it was "thrilling and fun" and another wrote, "I gradually got to explain my ideas more succinctly." Another student noted that she wanted to study English harder so that she could express her thoughts more concisely. For these students, the pressure of having a shorter time to communicate each time they talked to a new partner worked in positive ways, meeting their need to feel a sense of competence after successfully completing the task. None of the students expressed anxiety or negative feelings arising from the time pressure.

When the students were asked to share thoughts on this project, five students mentioned that they had not been very knowledgeable on the cultural significance of the New Year's cuisine, and they enjoyed discovering some interesting facts through their own research and discussion with friends. Though this was not intended, this project created an opportunity to raise the students' cultural self-awareness using English as a medium for communication, which they found to be motivating.

\section{Conclusions}

In this paper I have introduced and examined the effectiveness of a small-scale creative project in secondary-level students' classes in fostering their intrinsic motivation for English learning and improving their confidence in expressing their ideas in the target language. Through my in-class observations and the students' reflective comments, it can be concluded that creative projects have the potential to be an effective educational tool in achieving these goals.

Nonetheless, no systematic frameworks were utilized for the evaluation of the effectiveness, and this prevented me from gaining a clearer and more overarching understanding of the pedagogical value of this type of project. To conduct more accurate and in-depth analysis of how this type of creative projects can meet the goals, further investigation with a carefully crafted evaluative framework, one that enables practitioners to examine how a task affects the students' motivation as well as the basic psychological needs of sense of competence, relatedness, and autonomy, is necessary.

Another possible improvement to be considered is the utilization of educational technology to integrate more collaborative work among the students into the project work. Given the particular learning environment, in which the students meet each other only a few to several hours a month, opportunities for face-to-face collaboration are extremely limited. This condition made the creative project less student-centered, collaborative, or dynamic than would be otherwise possible. Working on the creative projects using an online discussion platform that allows students to keep in contact, share resources online, and engage in discussions outside the classroom (such as Padlet, Flipgrid, and Edmodo) may further improve the students' motivation for learning English, confidence in communicating using the language, and skills necessary for autonomous learning. Furthermore, for these "digital natives"-students who grew up with ubiquitous technology (Prensky, 2001)-the use of online platforms may have positive impacts on learning that are beyond my imagination.

\section{Bio Data}

Mari Nakamura designs curricula and teaches young learners and teenagers at her own language school, English Square, in Kanazawa City, Japan, while lecturing part-time at Kanazawa University. She earned a master's degree in TEYL from Aston University and has been volunteering as a co-editor of the JALT TLT Younger Learners Column since 2015. She gave a plenary address on her main interests, learner agency and online intercultural exchange projects, at the JALT2019 International Conference. <mari-@ pop02.odn.ne.jp>

\section{References}

Beckett, G. H., \& Slater, T. (2005). The project framework: A tool for language, content, and skills integration. ELT Journal, 59(2), 108-116. https://doi.org/10.1093/eltj/cci024

Benesse Educational Research and Development Institute. (2014). 中高生の英語学習に関する実態調 查 [Fact finding research of English language study among secondary school students] Retrieved from https://berd.benesse.jp/up_images/research/Teenagers_English_learning_Survey-2014_ALL.pdf

Berkeley, M. (2017). The role of the teacher in high quality PBL. Getting smart. Retrieved from https://www.gettingsmart.com/2017/04/role-teacher-student-centered-learning/

Brown, H. D. (2000). Principles of language learning and teaching (4th ed.). White Plains, NY: Pearson Education.

Brown, H. D. (2004). Language assessment: Principles and classroom practice. White Plains, NY: Pearson Education.

Buck Institute for Education. (2018). Gold standard PBL: Essential project design elements. Retrieved from https://www.pblworks.org/what-is-pbl/gold-standard-project-design 
Carreira, J. M. (2006). Motivation for learning English as a foreign language in Japanese elementary schools. JALT Journal, 28(2), 135-157. https://doi.org/10.37546/JALTJJ28.2-2

Deci, E. L., \& Ryan, R. M. (1985). Intrinsic motivation and self-determination in human behavior Boston, MA: Springer. https://doi.org/10.1007/978-1-4899-2271-7

Deci, E. L., \& Ryan, R. M. (1994). Promoting self-determined education. Scandinavian Journal of Educational Research, 38(1), 3-14. https://doi.org/10.1080/0031383940380101

Dörnyei, Z., \& Ushioda, E. (2013). Teaching and researching: Motivation (2nd ed.). New York, NY: Routledge.

Ertmer, P. A., \& Simons, K. D. (2006). Jumping the PBL implementation hurdle: Supporting the efforts of K-12 teachers. Interdisciplinary Journal of Problem-Based Learning, 1(1). https://doi. org/10.7771/1541-5015.1005

Farouck, I. (2016). A project-based language learning model for improving the willingness to communicate of EFL students. Systematics, Cybernetics and Informatics, 14(2), 11-18. Retrieved from http://www.iiisci.org/journal/sci/Home.asp

Gardner, R. C. (1983). Learning another language: A true social psychological experiment. Language and Social Psychology, 2(2-3-4), 219-240. https://doi.org/10.1177\%2F0261927X8300200209

Gardner, R. C. (1985). Social psychology and second language learning: The role of attitudes and motivation. London, England: Edward Arnold.

Harmer, J. (2015). The practice of English language teaching. Harlow, Essex, England: Pearson Education.

Kokotsaki, D., Menzies, V., and Wiggins, A. (2016). Project-based learning: A review of literature Improving schools, 19(3), 267-277. https://doi.org/10.1177/1365480216659733

Matsuno, S. (2018). Japanese learners' consciousness toward English: When do they begin to like or dislike English? The Language Teacher, 42(4), 19-23. https://doi.org/10.37546/JALTTLT42.4-4

Maurice, K. (1983). The fluency workshop. TESOL Newsletter, 17(4), 29. Retrieved from https://files. eric.ed.gov/fulltext/ED289347.pdf

MEXT. (2019). 第17回21世紀出生時縱断調查(平成13年出生児)の結果. [The result of the 17th survey of the students born in the 21st century (students born in 2001)] Retrieved from https://www.mext. go.jp/b_menu/toukei/chousa08/21seiki/kekka/__icsFiles/afieldfile/2019/08/30/1420755_001_1. pdf

OECD. (2017). Results from PISA 2015 students' well-being country note Japan. Retrieved from https://www.oecd.org/pisa/PISA2015-Students-Well-being-Country-note-Japan.pdf

Prensky, M. (2001). Digital natives, digital immigrants Part 1. On the Horizon, 9(5), 1-6. https://doi. org/10.1108/10748120110424816
Ryan, R. M., \& Deci, E. L. (2000). Self-determination theory and the facilitation of intrinsic motivation, social development, and well-being. American Psychologist, 55(1), 68-78. https://doi. org/10.1037/0003-066X.55.1.68

Ryan, R. M., \& Deci, E. L. (2008). From ego depletion to vitality: Theory and findings concerning the facilitation of energy available to the self. Social and Personality Psychology Compass, 2(2), 702 717. https://doi.org/10.1111/j.1751-9004.2008.00098.x

Oxford, R., \& Shearin, J. (1994). Language learning motivation: Expanding the theoretical framework. Modern Language Journal, 78(1), 12-28. https://doi.org/10.1111/j.1540-4781.1994 tb02011.x

Sakai, C. (2009). 中学生の英語学習状況之学習意欲 Uunior high school students' English language learning and motivation for the learning]. Retrieved from http://berd.benesse.jp/berd/center/open/ report/chu_eigo/hon/pdf/data_06.pdf

Smithers, R. W. (2014). Using projects to increase autonomy, motivation and language learning. Osaka JALT Journal, 1, 19-32. Retrieved from http://static1.1.sqspcdn.com/static /f/462558/27533618/1492785028830/OsakaJALTJournalMarch2014.pdf?token=yOm1dvmTZRb WDlwIDPbhTqBiT4w\%3D

Thomas, J. T. (2000). A review of research on project-based learning. Retrieved from https://www.asec. purdue.edu/lct/HBCU/documents/AReviewofResearchofProject-BasedLearning.pdf

Tsiplakides, I., \& Fragoulis, I. (2009). Project-based learning in the teaching of English as a foreign language in Greek primary schools: From theory to practice. English Language Teaching, 2(3), 113-119. https://doi.org/10.5539/elt.v2n3p113

Yamamori, K. (2004). 中学校1年生の4月における英語学習に対する意欲はどこまで持続するのか [Durability of the will to learn English: A one-year study of Japanese seventh graders]. 教育心理学 研究 [Educational Psychological Research], 52(1), 71-82. https://doi.org/10.5926/jjep1953.52.1_71 